\title{
Corporate bonds market development in Poland (2009-2015)
}

\author{
Arkadiusz Babczuk \\ Wrocław University of Economics \\ Wrocław, Poland \\ arkadiusz.babczuk@ue.wroc.pl
}

\author{
Marian Kachniarz \\ Wrocław University of Economics \\ Wrocław, Poland \\ marian.kachniarz@ue.wroc.pl
}

Zbigniew Piepiora

Wrocław University of Environmental and Life Sciences

Wrocław, Poland

zbigniew.piepiora@up.wroc.pl

\begin{abstract}
The article presents the review of organization and functioning of corporate bonds market in Poland from 2009 till 2015. It analyzes the main characteristics of this market -value of bond issued, owners of polish corporate bonds, typical maturity of issued bonds and institutional arrangements of secondary market.
\end{abstract}

Keywords-financial markets, non-government debt instruments, corporate bonds

\section{INTRODUCTION}

One of the components of transformation of Polish economy has been reintroduction of financial market, i.e. a market trading in medium or long-term credits or loans (credit-loan market) and medium or long-term securities (securities market). One of the most important types of securities traded on financial market are bonds.

Bond is a security issued in series, in which the issuer states the existence of his debt towards bondholder and takes an obligation to provide him with definite benefits, which may be of pecuniary or non-pecuniary character. A pecuniary benefit may consist in paying back the capital alongside with additional dues (interest, discounts). A non-pecuniary benefit may take the form of:

a) right to participate in issuer's future profits (participating bonds),

b) right to exchange bonds into common stock of the issuing company (convertible bonds),

c) priority right to acquire future common stock of the issuing company.

Polish debt market is predominated with Treasury bonds. However, this type of securities can also be issued by other entities like:

- joint stock companies or public limited companies (corporate bonds),
- territorial authorities and their associations as well as the capital city of Warsaw (municipal bonds),

- financial cooperatives

- financial institutions, especially banks $[17 ; 18]$.

The corporate bonds market was developed in the United States in the 19th century. It was connected with the issuances concerning infrastructural projects [3; 4]. Polish companies returned to bond market in 1996 [1].

In Poland bond issues, including corporate bonds, can be brought out by two methods:

1) purchase option offered to selected persons, whose number may not exceed 150 (private offer),

2) public subscription.

a) being a form of public turnover of securities,

b) not being a form of public turnover of securities,

Public bond subscription is not a form of public turnover of securities if the following conditions are jointly met:

- bonds represent pecuniary obligations only,

- their maturity period is shorter than a year $[17 ; 18]$.

These so-called short-term bonds are one form of short-term securities traded on money market. As such they are not included in this article.

\section{DEVELOPMENT}

The beginnings of polish non-government debt market was dominated by short-term securities (Commercial Papers CP). In $90^{\text {th }}$ this type of debt instrument constitute $75 \%$ of total market value. Over the years, this situation has changed remarkably. Nowadays polish non-government debt market is dominated by bonds of enterprises and banks (Table 1). We have also municipal bonds and short-term debt instruments available, but their share is definitely smaller. 
After the fall of Lehman Brothers in 2009, many companies realized that having only one source of funding in the form of a bank loans is too risky. They want to diversify sources of funding using the stock market and the debt securities market (Table 2). We can notice many new issuances-mainly due to the Energy sector. Currently, the share of bonds in the newly incurred liabilities of polish enterprises amounted to almost $40 \%$ [2, p. 13]. However, in the case of an issuance of bonds, we observe higher spreads than in the bank loans market. It is connected with the lack of collateral. [2, p. 31].

At the end of 2009 the value of the corporate bond market with maturities over 365 days amounted to 12,16billion (bn.) zlotys (PLN).In 2010 the value of the corporate bond market increased to PLN 17,58 bn. At the end of 2011 the value of the corporate bond market amounted to PLN 24,19 bn. In 2012 the value of the corporate bond market increased to PLN 31,36 bn.

TABLE I. NOMINAL VALUE OF POLISH NON- GOVERNMENT DEBT MARKET, DECEMBER 31, 2009 - SEPTEMBER 31, 2015 (IN BN. PLN)

\begin{tabular}{|l|c|c|r|r|r|}
\hline \multirow{2}{*}{ Year } & \multicolumn{5}{|c|}{ Type of instruments } \\
\cline { 2 - 6 } & $\mathbf{C P}$ & $\begin{array}{c}\text { Corporate } \\
\text { Bonds }\end{array}$ & $\begin{array}{c}\text { Bank } \\
\text { bonds }\end{array}$ & $\begin{array}{c}\text { Municipal } \\
\text { bonds }\end{array}$ & \multirow{2}{*}{ Total } \\
\hline 2009 & 9,97 & 12,16 & 18,97 & 6,91 & 47,99 \\
\hline 2010 & 14,79 & 17,58 & 24,05 & 10,85 & 67,28 \\
\hline 2011 & 22,25 & 24,19 & 36,75 & 14,35 & 97,54 \\
\hline 2012 & 26,37 & 31,36 & 44,37 & 15,62 & 117,71 \\
\hline 2013 & 19,15 & 37,79 & 47,77 & 18,55 & 123,26 \\
\hline 2014 & 19,04 & 52,68 & 48,61 & 19,11 & 139,44 \\
\hline Q3 2015 & 13,56 & 62,00 & 51,16 & 19,23 & 145,95 \\
\hline
\end{tabular}

TABLE II. POLISH NON- GOVERNMENT DEBT MARKET, ISSUES PLACED IN THE FOLLOWING YEARS, 2012 - 2015 (IN BN. PLN)

\begin{tabular}{|l|r|r|r|r|}
\hline \multirow{2}{*}{ Year } & \multicolumn{4}{|c|}{ Type of instruments } \\
\cline { 2 - 5 } & $\begin{array}{c}\text { Corporate } \\
\text { Bonds }\end{array}$ & Bank bonds & $\begin{array}{c}\text { Municipal } \\
\text { bonds }\end{array}$ & \multicolumn{1}{c|}{ Total } \\
\hline 2012 & 12,75 & 12,21 & 2,58 & 27,55 \\
\hline 2013 & 12,67 & 7,18 & 4,46 & 24,31 \\
\hline 2014 & 21,28 & 11,23 & 2,12 & 34,63 \\
\hline Q3 2015 & 14,74 & 6,64 & 0,70 & 22,08 \\
\hline
\end{tabular}

At the end of 2013 the value of the corporate bond market amounted to PLN 37,79 bn. In 2014 the value of the corporate bond market increased rapidly to PLN 52,68 bn. Table 2 shows that in the last year more than PLN 21 bn. were issued in corporate bonds on the domestic market. In 3Q2015 the value of the corporate bond market amounted to PLN 62 bn. Thus, we can still observe speedy market growth. At the end of September 2015, corporate bond issues constituted $42,48 \%$ of the total non-government debt market value.

Table 3 shows the purchaser of corporate bonds structure. The main investors on the polish corporate bonds market are commercial banks, especially banks organizing bonds issue process. Nowadays, they own above 33,3\% of polish corporate bonds (Table 4). The second type of investors is other enterprises. From the enterprises' point of view, investing in this type of financial instrument is an alternative to deposits in banks. Less than one-third of the purchasers are institutional investors such as insurance companies, investment funds, pension funds. Thus, in terms of the investor structure, the Polish corporate bonds market is very different from international markets, where this type of investors plays a leading role. Foreign entities in Poland are of marginal importance.

TABLE III. POLISH CORPORATE BONDS IN INVESTORS' PORTFOLIOS IN THE FOLLOWING YEARS, 2011 - 2015 (IN BN. PLN)

\begin{tabular}{|c|c|c|c|c|c|c|}
\hline \multirow[b]{2}{*}{ Year } & \multicolumn{6}{|c|}{ Type of investors } \\
\hline & 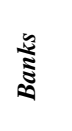 & 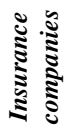 & 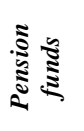 &  & 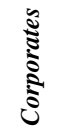 & 胥: \\
\hline 2011 & 7,82 & 1,11 & 3,13 & 5,42 & 3,50 & 1,09 \\
\hline 2012 & 8,26 & 2,22 & 4,15 & 3,82 & 4,49 & 1,33 \\
\hline 2013 & 10,85 & 1,59 & 3,67 & 7,27 & 9,01 & 1,17 \\
\hline 2014 & 20,04 & 1,55 & 2,92 & 8,75 & 16,07 & 2,00 \\
\hline Q3 2015 & 20,65 & 1,59 & 2,70 & 9,44 & 22,70 & 2,18 \\
\hline
\end{tabular}

TABLE IV. POLISH CORPORATE BONDS IN INVESTORS' PORTFOLIOS IN THE FOLLOWING YEARS, 2011 - 2015 (IN \%)

\begin{tabular}{|c|c|c|c|c|c|c|}
\hline \multirow[b]{2}{*}{ Year } & \multicolumn{6}{|c|}{ Type of instruments } \\
\hline & $\frac{\tilde{a}}{\tilde{\Xi}}$ & 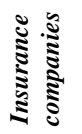 & 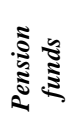 &  & \begin{tabular}{l}
\multirow{\Xi}{*}{} \\
$\vdots$ \\
$\vdots$ \\
0
\end{tabular} & క: \\
\hline 2011 & 32,33 & 4,59 & 12,94 & 22,41 & 14,47 & 4,51 \\
\hline 2012 & 26,34 & 7,08 & 13,23 & 12,18 & 14,32 & 4,24 \\
\hline 2013 & 28,71 & 4,21 & 9,71 & 19,24 & 23,84 & 3,10 \\
\hline 2014 & 38,04 & 2,94 & 5,54 & 16,61 & 30,50 & 3,80 \\
\hline Q3 2015 & 33,31 & 2,56 & 4,35 & 15,23 & 36,61 & 3,52 \\
\hline
\end{tabular}

Most issues of corporate bonds during the 2009-2015 period were non-public, i.e. they were brought out by offering them to not more than 150 individual, specified investors. Almost all polish corporate bonds are repaid on a bullet repayment basis (repayment of the entire capital at maturity) [2, p. 31]. Polish corporate bonds market is dominated by common money bonds, but we have also convertible bonds. Convertible bonds usually bear much lower interest than that on common money bonds, in return offering the bondholder a chance to participate in the possibly increased future value of the company. Currently we have the new type of bonds to the Polish market - revenue bonds. In essence, these bonds are serviced with revenues brought by the project or project property which was financed with the issue [17].

Polish corporate bonds market is dominated by variable coupon bonds. There are more than $80 \%$ of them. Interest on common money bonds based on interest rates offered at interbank market (WIBOR) plus spread. Nowadays, the share of fixed-rate bonds is about $17 \%$ [2, p. 24].

Figure 1 shows that more than $53,9 \%$ of polish corporate bonds issues are short issues, with a maturity of up to 3 years. 
Only in the case of big companies, we can observe issues withlonger maturity, up to 23 years.

In Poland average issue volume of corporate bonds is approx. 50 million zlotys. It is far away from the European or American corporate bonds markets standards. Polish economy is based on small and medium enterprises. Thus, we should expect small corporate debt issuances.

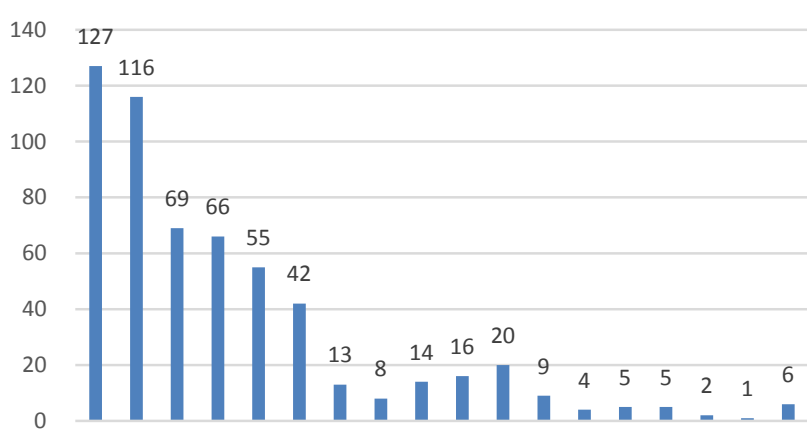

$\begin{array}{llllllllllllllllll}1,2 & 3 & 4 & 5 & 6 & 7 & 8 & 9 & 10 & 11 & 12 & 13 & 14 & 15 & 16 & 17 & 22 & 23\end{array}$

Figure 1 Number of issues with given maturity in 2014

Source: [2, p. 12].

The vast majority of polish corporate bonds issues does not have a rating. Fortunately, the largest ones are rated.

On the 30thof September 2009 was created new organized secondary market for polish debt securities, called Catalyst market. The valuation shaped by the organized market is considered as a better one than valuation based on OTC transactions. Thus, it was an important factor which stimulates to rise of polish corporate bonds market. Debt instruments are traded on the markets organized by two companies of the Warsaw Stock Exchange (WSE) capital group (WSE itself and its subsidiary, BondSpot SA). Thus, debt instruments are traded in two places and through two listing systems. However, Catalyst comprises four trading platforms. Two of them are operated by the WSE: as a regulated market and an alternative trading system (ATS) for retail customers. The two other platforms are dedicated to wholesale customers and are operated by BondSpot as a regulated market and an ATS. Execution of transactions on all Catalyst markets is guaranteed by the National Depository for Securities. Issuers are bound by reporting requirements including current and periodic reports.

Currently, Corporate bonds are the fastest-growing segment of the Catalyst market[2, p. 30]. We sometimes notices corporate bonds defaults, but the default risk is moderate and related to a larger extent mainly by issues of lesser value [2, p. 27].

\section{CONCLUSIONS}

In the summary of the above presented discussion it can be concluded that the significance of corporate bonds on the
Polish securities market steadily grows. It particularly refers to the countries which are experiencing systemic transformations. However, one of the biggest problems of polish corporate bonds market is lack of documents standardization. It complicates issues process and makes it more costly.

Currently companies' access to bond market has been significantly easier, due to new Bond Act, passed by the Polish Parliament on 15.01.2015. It introduced possibility to issue bonds through a special-purpose company. Furthermore, it makes precise that foreign entities may conduct issuances in Poland. In addition, a new type of perpetual bonds was introduced.

One of the last biggest problems of polish corporate bonds market is lack of documents standardization. It complicates issues process and makes it more costly and timeconsuming. Thus, polish government should cooperate with market participants to solve it.

\section{REFERENCES}

[1] A. Babczuk,Skarbowe papaiery wartościowe jako instrument zarzadzania dtugiem publicznym [Treasury Securities as Public Debt Management Instrument] Jelenia Góra 1999

[2] T. Gałka, A. Gontarek, P. Kowalski, Corporate debt securities market in Poland: state of art, problems, and prospects for development, mBank CASE Seminar Proceedings No. 136/2015, Warsaw 2015

[3] E.F. Fama, M.H. Miller, The theory of finance, Holt Rinehart \& Winston, New York 1972

[4] F. Fabozzi, Bond Markets, Analysis, and Strategies, Prentice Hall, Upper Saddle River 2000

[5] F. Fabozzi, The Handbook of fixed income securities, McGraw-Hill, 2005

[6] M. Harris, A. Raviv, The Theory of Capital Structure, „The Journal of Finance” 1991 vol. 46, no. 1, s. 297-355

[7] Introducing the mBank Polish Corporate Bonds Index (mBank PCBI). Rules and Methodology, www.mBank.pl

[8] F. Modigliani, M.H. Miller, The cost of capital, corporation finance and the theory of investment, „The American Economic Review” June 1958 vol. XLVIII, s. 261-297

[9] S.C. Myers, Determinants of corporate borrowing, „Journal of Financial Economics” 1977 vol. 5, s. 147-175

[10] Polish non - government debt market: Q4 2009 and 2009 summary, FitchRatings, Warsaw 2010

[11] Polish non - government debt market: Q4 2010 and 2010 summary, FitchRatings, Warsaw 2011

[12] Polish non - government debt market: Q4 2011 and 2011 summary, FitchRatings, Warsaw 2012

[13] Polish non - government debt market: Q4 2012 and 2012 summary, FitchRatings, Warsaw 2013

[14] Polish non - government debt market: Q4 2013 and 2013 summary, FitchRatings, Warsaw 2014

[15] Polish non - government debt market: Q4 2014 and 2014 summary, FitchRatings, Warsaw 2015

[16] Polish non - government debt market: Q3 2015 summary, FitchRatings, Warsaw 2015

[17] Report on the review of financial statements by issuers of securities in the context of their compliance with IFRSs. The Review caried out in 2014. Polish Financial Supervision Authority, Warsaw, February 2015

[18] Republic of Poland. Selected Issues, IMF, Washington, D.C. 2014. 